\title{
INTER-SECTORAL SUPPORT ON THE ACCREDITATION OF COMMUNITY HEALTH CENTER, SOUTH KONAWE, SOUTH EAST SULAWESI
}

\author{
Abdul Samad, Mustamin \\ Masters Program in Public Health, School of Health Sciences Mandala Waluya, Kendari
}

\begin{abstract}
Backgrounds: Being one of the most important elements in healthcare system, Community Health Center has been promoted to improve its quality and capacity of services. Accreditation is a method that can be used to improve and measure the quality of health service. This study aimed to examine the associations between inter-sectoral support on the accreditation of community health center.

Subjects and Method: A qualitative study with case study approach was conducted in Kendari, South East Sulawesi. A total of 24 community health centers was selected for this study. A total of 26 key informants was selected including 8 heads of community health center, 2 staff of South Konawe District Health Office, 8 head of sub-district, and 8 heads of village. The dependent variable was accreditation of community health center. The independent variable was inter-sectoral support. The data were collected by in-depth interview and processed using descriptive method.

Results: As many as 8 of 24 community health centers (33.3\%) were accredited, consisting of 5 madya (medium) accredited, 3 pratama (basic) accredited. Community health center with medium accreditation status had better inter-sectoral support than those with basic accreditation status.

Conclusion: As many as $33 \%$ of all community health centers in Kendari, South East Sulawesi, have already accredited. Community health center with medium accreditation status have better inter-sectoral support than those with basic accreditation status.
\end{abstract}

Keywords: accreditation, inter-sectoral, community health center

\section{Correspondence:}

Abdul Samad. Masters Program in Public Health, School of Health Sciences Mandala Waluya, Jl. A.H.Nasution No. G 37, Kendari, South East Sulawesi.

Email: abdulsamadsultra@gmail.com. Mobile: 082324237775.

The 5th International Conference on Public Health Best Western Premier Hotel, Solo, Indonesia, February 13-14, 2019 | 450 